control purposes with the more conventional layout of the various aerodynamic surfaces. The Westland-Hill 'Pterodactyl' demonstrated the possibilities of tailless aircraft many years ago. The suppression of as much of the extermal body as practical requirements of accommodation allow is another obvious trend for the same reason.

Experimental work on high-speed flight has made it evident that swept-back wings are going to be inevitable at transonic and supersonic flight speeds. Again the vital factor appears to be that of control with the less conventional lay-out of the wing surfaces. The A.W.52 follows a series of experiments carried out with gliders, and appears to be satisfactory in this respect. Further progress towards even higher speeds should be possible now that greater powers can be envisaged using the internal combustion turbine in conjunction with jet propulsion, and this or similar machines will undoubtedly be used in this way.

\section{Falkland Islands Dependencies Survey}

The Falkland Islands Dependencies Survey has recently acquired a vessel to enable it to carry out its expanding field of work in the Antarctic. The ship, which was named John Biscoe by Mrs. Creech Jones, wife of the Secretary of State for the Colonies, on December 16, has a double-skin wooden hull and a displacement of 1,015 tons; she is driven by Dieselelectric power. She carries a crew of twenty-five, and is to take a relief party in the summer to replace about half the party at present occupying the seven observation stations maintained by the Survey in the Antarctic. The new party will carry out geological, meteorological and zoological investigations, and is under the leadership of Dr. V. E. Fuchs, a geologist who has had experience of exploration in East Greenland and in East Africa. The John Briscoe has been named in memory of the discoverer of the southern part of Graham Land. The Falkland Islands Dependencies Survey (see Nature, March 22, p. 388) was set up under the control of the Colonial Office after the War to take over from the Admiralty the meteorological stations established in the Antarctic in 1943.

\section{Royal Society: Research Appointments}

THe Royal Society has appointed Dr. K. Bailey, of the Biochemical Laboratory, Cambridge, to an Alan Johnston, Lawrence and Moseley Research Fellowship for research on the problems of human and animal health and diseases and the biological field related thereto. Dr. Bailey will work at the Biochemical Laboratory in Cambridge on the proteins of muscle fibril. The Royal Society has also appointed Dr. G. S. Dawes, of Worcester College, Oxford, to a Foulerton Research Fellowship in Medicine. Dr. Dawes will work at the Department of Pharmacology, Oxford, on the left ventricle reflex.

\section{Edward Rigby (1747-182I)}

EDWARD RIGBY, who was born at Chowbent in Lancashire two hundred years ago on December 27, was a versatile man, distinguished alike in obstetrics, agriculture and civic administration. In medical literature his "Essay on the Uterine Hæmorrhage" (1775) is regarded as a classic, for it clearly differentiated between premature separation of the normal placenta (accidental hæmorrhage) and placenta prævia (unavoidable hæmorrhage). It was translated into Fronch and German, and up to the hour of his last illness the author was employed in the preparation of a sixth edition. A scientific agriculturist, Rigby experimented on his own farm at Framingham Earl, near Norwich, and the reputation of his writings on that subject led to his election as honorary member of the Philadelphia Society. In 1805 he became mayor of Norwich, and he is said to have "supported the chair with dignity and hospitality". He estab. lished in 1786 the Norfolk Benevolent Medical Society for the relief of the widows and orphans of medical men, introduced the flying shuttle to the manufacturers in Norwich, and in 1812 started vaccination in the city. Simple, placid and benevollent, Rigby was a delightful companion and a good conversationalist. He died on October 27, 1821, in his seventy-fourth year. His "Letters from France" constitute an animated and fascinating record of the stirring days at the outbreak of the French Revolution, besides forming a useful survey of the country's agriculture at the time. Rigby's son Edward (1804-60) was a well-known London obstetrician.

\section{New Nuclear Reactions}

"NuClear Transformations in the now High Energy Ranges" is the title of an address delivered by Prof. Glenn T. Seaborg, of the University of California, at a meeting of the American Chemical Society in New York on September 15 (see Chemical and Engineering News, 25, 2819; 1947). The great progress made recently in constructing new powerful machines for the acceleration of charged particles affords the possibility of bombarding targets with electrons of $100 \mathrm{MeV}$., and with deuterons and helium ions of 200 and $400 \mathrm{MeV}$. respectively. Entirely new nuclear reactions have been observed; for example, ${ }_{33}^{75} \mathrm{As}$, bombarded with $400 \mathrm{MeV}$. helium ions, produces among other atomic species the well-known ${ }_{17}^{38} \mathrm{Cl}$. This means that the arsenic atom has lost no less than 16 protons and 21 neutrons, not counting the two protons and two neutrons shot into it at the start of the reaction. To distinguish such transmutations from the ordinary nuclear reactions in which only one or two particles are ejected, and from fission reactions in which the nucleus is broken into two fragments, the term 'splintering reaction' is proposed. Further, under such strong bombardment fission can be enforced in such elements as bismuth, lead and thallium, and even in an element so low in the periodic table as tantalum; but as the secondary particles emitted have a much smaller energy, there is no possibility of inducing a chain reaction such as in uranium. Many radioactive isotopes so far unknown have been found as a result of these new nuclear reactions, which have still further widened the field radiochemists are called upon to explore; the splintering often leads to neutron-deficient isotopes and increases therefore in a welcome manner the comparatively small number of positron emitters among the artificial radio-elements. Some of them may find application as tracers. Still more important may be the physical aspects of this extension of the energy range; the creation from energy of mesotrons and, if the region of billions of electron-volts can be reached, also of neutrons and protons, seems now a possibility.

\section{Special Libraries in Australia}

RAPID growth in the appreciation of the value of accurate and up-to-date information in science and technology was marked during the last decade. This 